\title{
METHOD FOR OPTIMUM CALCULUS OF MACHINING PARAMETERS ACCORDING TO TOOL TRAJECTORIES TYPE BASED ON MILLING PROCESS SIMULATION
}

\author{
Andra Elena Pena, Florea Dorel Anania, Cristina Mohora
}

Original scientific paper

Virtual manufacturing systems can provide useful means for products to be manufactured without the need of physical testing on the shop floor. As a result, the time and cost of part production can be decreased. The paper presents the influence of tool path trajectory on surface deviation geometry when finishing inclined surfaces. The aim of the study is to optimize the milling process taking into account the milling strategy. The research was focused on ball end finishing because it is well known that in plain cutting, in the centre of the flat mill the cutting speed is $v_{\mathrm{c}}=0 \mathrm{~m} / \mathrm{min}$. According to that, the surface roughness is influenced by the fact that in this area a friction process occurs and not a cutting process. Six types of tool trajectories were simulated and surface deviation was evaluated.

Keywords: cusp height; finishing milling; simulation; surface texture; tool path

Metoda optimalnog proračuna parametara obrade prema vrsti putanje alata simulacijom postupka glodanja

Izvorni znanstveni članak Virtualni obradni sustavi mogu biti od koristi u izradi proizvoda za koje nije potrebno fizičko ispitivanja u radionici. Kao rezultat, može doći do smanjenja vremena i troška izrade dijela. U radu se opisuje utjecaj putanje alata na devijaciju površinske geometrije kod završne obrade kosih površina. Cilj rada je optimizirati postupak glodanja uzimajući u obzir strategiju glodanja. Istraživanje je usmjereno na završnu obradu kuglaste glave jer je poznato da kod ravnog glodanja brzina glodanja u sredini glodala iznosi $v_{\mathrm{c}}=0 \mathrm{~m} / \mathrm{min}$. U skladu s tim, na hrapavost površine utječe činjenica da u tom području dolazi do postupka trenja a ne narezivanja. Simulirano je šest vrsta putanje alata i procijenjena je površinska devijacija.

Ključne riječi: površinska hrapavost; putanja alata; simulacija; visina šiljka; završno glodanje

\section{Introduction}

Nowadays milling free-form shapes surfaces using ball end mills is the subject of a lot of research papers. Sculptured surfaces are widely used in automotive, die/mould and aerospace industries [1]. Unlike traditional milling in milling free-form shapes, the contact between the cutting tool and the machined surface changes constantly. Furthermore, the centre of the ball-end tool, which has a zero cutting speed, can take part in the material removal process. The tool path is also responsible for such circumstances and although many papers can be found about the theme, the influences of the finishing tool path on the roughness of the machined surface are not stated yet $[2,3]$.

There is an endless number of variants for trajectories, with which the same free-form-shaped part can be worked. In complex strategies the load of the tool will vary (even for the same cutting direction) according to its position relative to the remaining stock from a previous trajectory [4]. As the radius of surface curvature varies from point to point but the tool shape can be accepted as unchangeable, then the most common type of contact of the tool surface and a part is the point contact [5].

The cutter path orientation is crucial in achieving desired machined surface and without considering the impact of cutting edge with undeformed chip in different path strategy with adequate consideration of the chip area variation, cutting forces, temperature and vibration analysis, the result can lead to cutter failure and therefore lead to unnecessary waste of time, cost and poor surface quality.

Frequently, manual polishing operations are necessary due to the machining surface and for reducing the polishing time and cost, appropriate tool path strategy should be selected to improve the dimensional accuracy, the surface roughness and minimal vibrations characteristics [6].

With the development of computers and digital environments a paradigm shift in manufacturing from 'real' to 'virtual' production has resulted in a build-up of research interests in the field. With the aid of computers, simulating and modelling of a physical manufacturing system become possible in virtual environments. The objective of simulating manufacturing technologies in virtual reality systems is to design a completely digital factory. The part is modelled and produced in a computer simulation environment with predicted errors in order to achieve the best accuracy in the produced part by choosing optimized process parameters. Virtual simulation provides a strong tool for producing and analysing parts in digital environments in order to decrease cost and time. The main objective is to understand and emulate the behaviour of a particular manufacturing system on a computer environment. As a result, a reduction of testing and experiments on the shop floor can be achieved. Machining accuracy of $\mathrm{CNC}$ machines is under influence of many errors which causes differences between designed and produced parts [7].

The continuous demand for higher productivity and product quality asks for better optimizing of the machining process.

Generally, the handbook or human experience is used to select convenient machine parameters in manufacturing industry. In process planning of conventional milling, selecting reasonable milling parameters is necessary to satisfy requirements involving machining economics, quality and safety.

Determination of the optimal cutting parameters (cutting conditions) such as the number of passes, depth of cut, speed, and feed is considered as a crucial stage of 
milling machining processes and especially in process planning.

Commercial $\mathrm{CAD} / \mathrm{CAM}$ systems provide various capabilities for surface design and process planning. An efficient process plan requires the establishment of proper operation sequences, including removal strategies, that is, tooling and tool performance.

\section{Surface quality in the ball end milling process}

The machined surface is one of the most studied subjects regarding quality when milling with a ball end mill [8]. Due to variability in technology such as cutting conditions, tool material/tool shape, milling strategy, etc., the resultant surface roughness varies widely by being affected by the type of produced surface and workpiece as well.

When finishing a component, the goal is to avoid or at least minimize the necessity for manual retouching. However, many factors influence the surface finish of a milled component: material, workpiece geometry, clamping, tool overhang and as seen in previous work, the tool trajectory.

The desired surface-roughness $R$ th definitively influences both final surface and the machining times needed for finishing. The selection of operation data to achieve a defined surface roughness saves valuable time in every finishing operation and ensures competitive machining times.

\section{Calculus method}

In the milling operations, the cutting tool performs a step over and makes several adjacent cuts. Between these cuts small cusps of material remain - cusps height which is translated in surface deviation geometry or surface roughness. The size of the step over and tool diameter will determine the cusp height between each step (see Fig. 1).

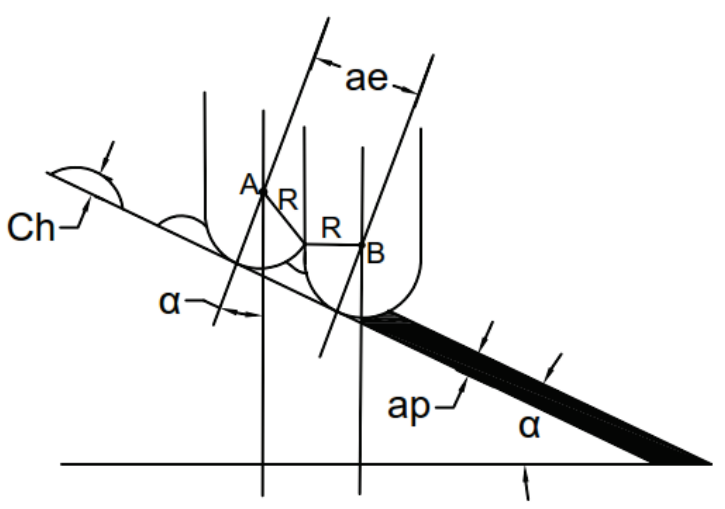

Figure 1 Geometrical elements of machined surface

In the case of a plain surface with inclination angle equal to zero, the cusp height can be calculated with the formula $(1)[9,10]$.

$\operatorname{ch}=\frac{D}{2}-\sqrt{\left(\frac{D}{2}\right)^{2}-\left(\frac{a_{e}}{2}\right)^{2}}$

If angle $\alpha \neq 0$, the theoretical cusp height depends on $\alpha$ as
$\operatorname{ch}=\frac{D}{2}-\sqrt{\left(\frac{D}{2}\right)^{2}-\left(\frac{a_{e}}{2 \cos \alpha}\right)^{2}}$

In the case of a ball end tool when milling inclined surfaces, the diameter of the tool is calculated with the formula [11]:

$d_{\mathrm{eff}}=d_{1} \cdot \sin \left(\alpha+\arccos \left(1-\frac{2 a_{\mathrm{p}}}{d_{1}}\right)\right)$

where: $d_{1}-$ tool diameter in mm; $\alpha$ - approach angle of tool axis in ${ }^{\circ} ; a_{\mathrm{p}}-$ depth of cut in $\mathrm{mm} ; d_{\text {eff }}-$ true tool diameter in action in $\mathrm{mm}$.

The tool used in this case is a $10 \mathrm{~mm}$ ball nose mill with 2 flutes.

The cutting regime parameters used for the machining process simulation are kept for all the trajectories at the same values $F=1500 \mathrm{~mm} / \mathrm{min}, n=7000 \mathrm{rpm}, v_{\mathrm{c}}=220$ $\mathrm{m} / \mathrm{min}, f_{\mathrm{z}}=0,10 \mathrm{~mm} /$ tooth, $a_{\mathrm{e}}=0,2 \mathrm{~mm}, a_{\mathrm{p}}=0,3 \mathrm{~mm}$.

According to the formula (3) and the data presented above, the true diameter of the tool in action, $d_{\text {eff }}$ is 9,2 $\mathrm{mm}$.

Based on the formula (2) and the cutting data presented, the value for the desired cusp height is obtained:

$c h=0,02$

Starting from the calculated value, the simulation is made to see the influence of tool path trajectory on surface deviation value.

\section{Simulation}

The scope of this research was to determine the effect of tool path strategy in finishing milling on surface deviation geometry as well as to compare the results with the calculation of cusp height according to Eq. (2).

This research is based on previous experimental data that were made on this subject [12]. The case studied was for milling a planar surface with $\alpha=0^{\circ}$. There were tested five types of different cutting tool trajectories using a 12 $\mathrm{mm}$ diameter end mill with 3 flutes. The conclusion was that the tool path type indeed influences the surface quality and after several measurements, a correction coefficient was determined which is applied to the feed conducted to a stabilization of surface roughness in a certain range.

Based on this research the next step is to analyse inclined surfaces milled with a ball end tool. This is made based on CAM simulation results, in order to limit the energy and material consumption.

The 6 areas were roughened by 3 axis milling, leaving a uniform amount of material of $0,3 \mathrm{~mm}$, to be removed by the finishing milling, The step over used is $0,2 \mathrm{~mm}$. The machining simulation is made in Cimatron E12.

The trajectories used are presented in Fig. 2. 


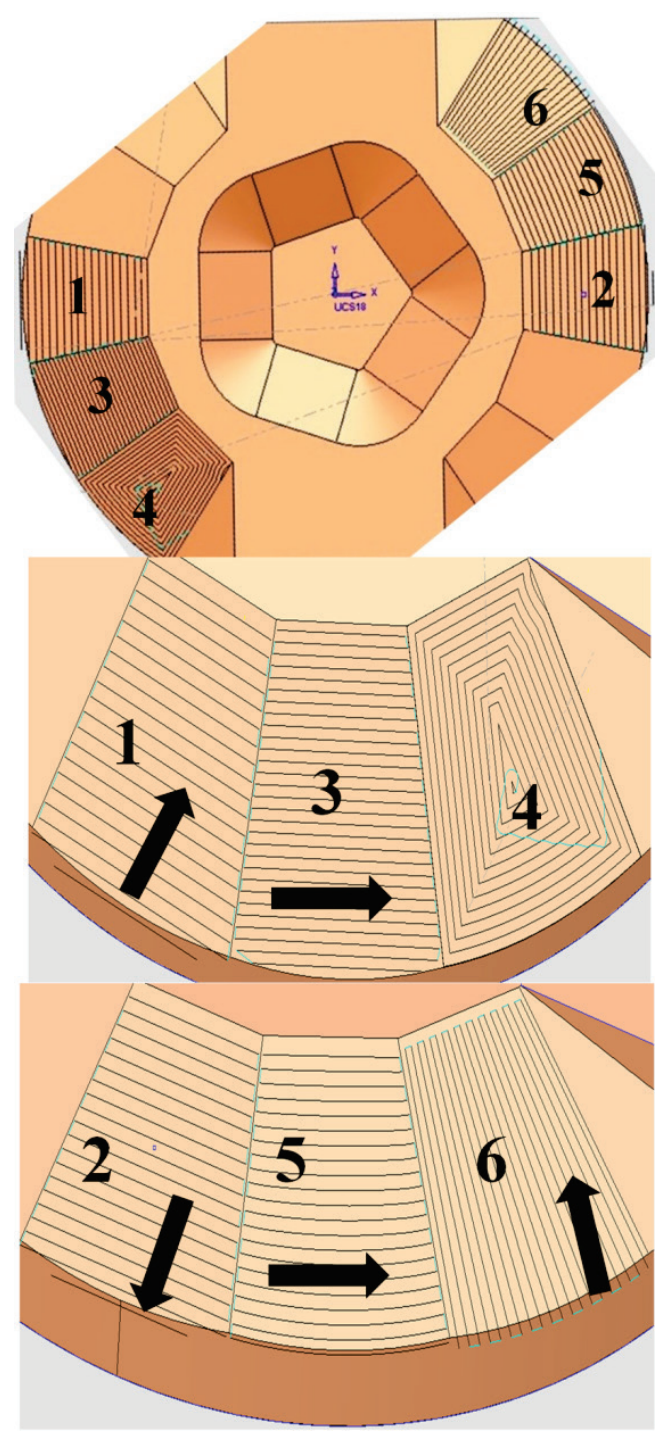

Figure 2 Trajectories types
Each of the 6 areas was finished by a different tool path strategy:

1 - perpendicular to $X$ axis from bottom to top

2 - perpendicular to $X$ axis from top to bottom

3 - parallel between top and bottom curves

4 - spiral from outside to inside

5 - between curves - top and bottom

6 - between curves - lateral.

In all cases is used both climb and conventional milling because the tool moves in zig-zag. The trajectories 1 and 2 are located symmetrically to the $X$ axis in order to analyse the influence of tool movement on surface quality. The trajectories 3 and 5 inclination in relation to $X$ axis is 22 degrees. So besides testing the trajectory type on surface roughness, the displacement from $X$ axis is also analysed. The trajectories that are alike are placed in mirror so that the displacement from $X$ is the same.

After simulating the machining process the resulting part was exported in STL format and analysed.

\section{Results}

The part obtained after machining simulation was compared with the original part and based on the measurements presented below the analysis was made.

The measurements were made in DeskartesView Expert 10. On each machined surface 10 points were determined on 3 different areas and on 2 directions. In Fig. 3 is presented an example of measurement from one area.

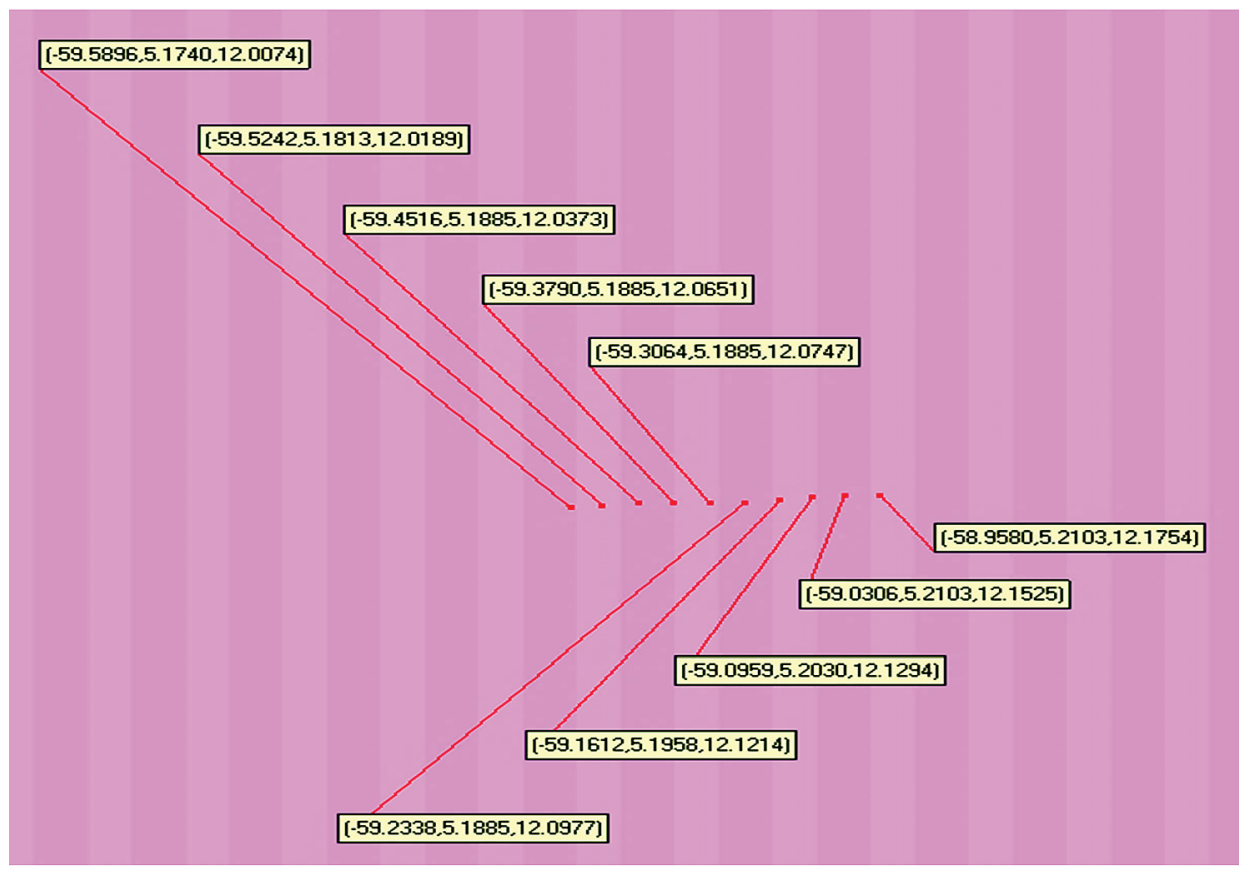

Figure 3 Deviation geometry measurement 
Averages were calculated for each direction of measurement and the results are presented in Fig. 4.

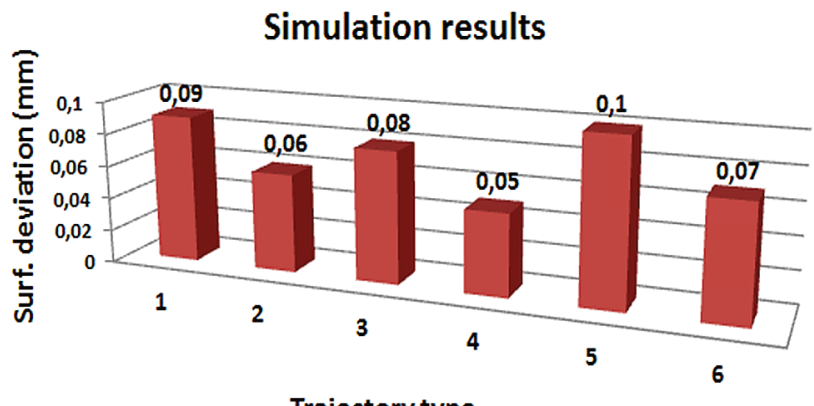

Trajectory type

Figure 4 Measurement results

The time that the tool is engaged on the material as well as its contact position with the machined surface alters according to the tool path strategy, what may influence tool wear. But, for finishing milling operation, the cost of the tool is not significant and, therefore, this point was not analysed in this paper.

However, after the first investigation, it was concluded that the cutting parameter step-over $\left(a_{\mathrm{e}}\right)$ could not be kept constant in all of the cases. It is because the options of finishing milling strategies change from horizontal, vertical and also radial trajectories as presented in Fig. 2.

So the goal is to find the step over that is suitable for every trajectory type in order to reduce the surface deviation. To do so a correction coefficient is determined by dividing each deviation value to the smallest one (see Eq. (4)) and the results are presented in Tab. 1.

$c_{s d}^{t}=\frac{s d^{t}}{s d^{r e f}}$

where: $t=1 \ldots 6-$ tool trajectories; $s d^{t}-$ reference surface deviation for each trajectory type; $s d^{\text {ref }}$ - constant reference value.

This coefficient is then used for recalculating the radial step over for each tool trajectory.

$a_{e}^{t}=\frac{a_{e}^{r e f}}{c_{s d}^{t}}$

where: $a_{e}^{r e f}$ - reference radial step over established by engineer; $a_{e}^{t}-$ radial step over for different type of trajectories $(t=1 \ldots 6)$.

Table 1 Correction coefficient

\begin{tabular}{|c|c|c|c|}
\hline Tool path & $\begin{array}{c}\text { Correction } \\
\text { coefficient } /-\end{array}$ & $\begin{array}{c}\text { Step over } \\
a_{\mathrm{e}} / \mathrm{mm}\end{array}$ & $\begin{array}{c}\text { Time } \\
/ \mathrm{s}\end{array}$ \\
\hline 1 & 1,8 & 0,11 & 4,47 \\
\hline 2 & 1,2 & 0,17 & 3,09 \\
\hline 3 & 1,6 & 0,13 & 3,39 \\
\hline 4 & 1 & 0,2 & 2,26 \\
\hline 5 & 2 & 0,1 & 4,55 \\
\hline 6 & 1,4 & 0,14 & 4,13 \\
\hline
\end{tabular}

After recalculating the step over based on the coefficients obtained (see Eq. (5)), another simulation was done and the results are presented in Fig. 5.

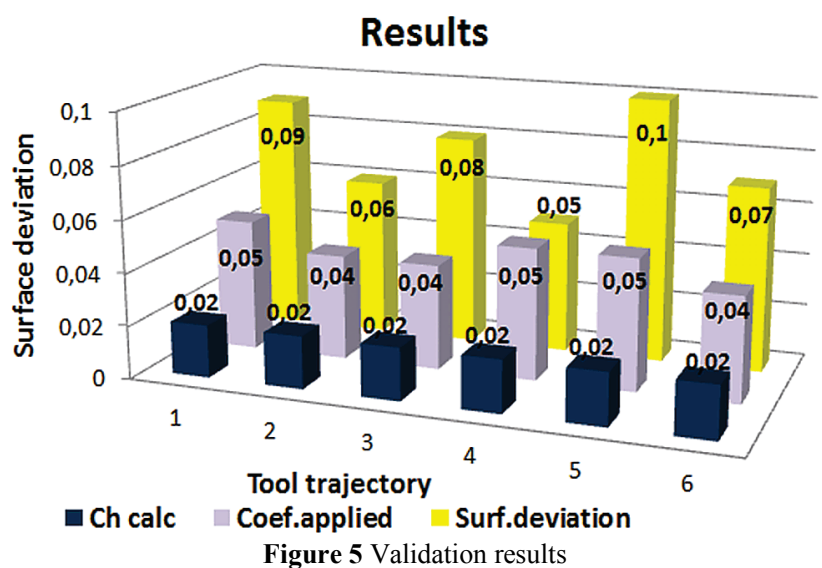

In the graph, "Chcalc" is represented by the value obtained after theoretical calculus (see Eq. (1)), "coef. applied" is the value of surface deviation after simulating the milling process with the step over calculated according to Eq.(5), and the "surf. deviation" is the initial measurement.

In Fig. 6 is represented the time measured after simulating the process with the initial calculated values of the cutting regime parameters ("classic calculus"), and the time after reducing the step over with the corresponding coefficient for every tool trajectory type ("coeff. applied").

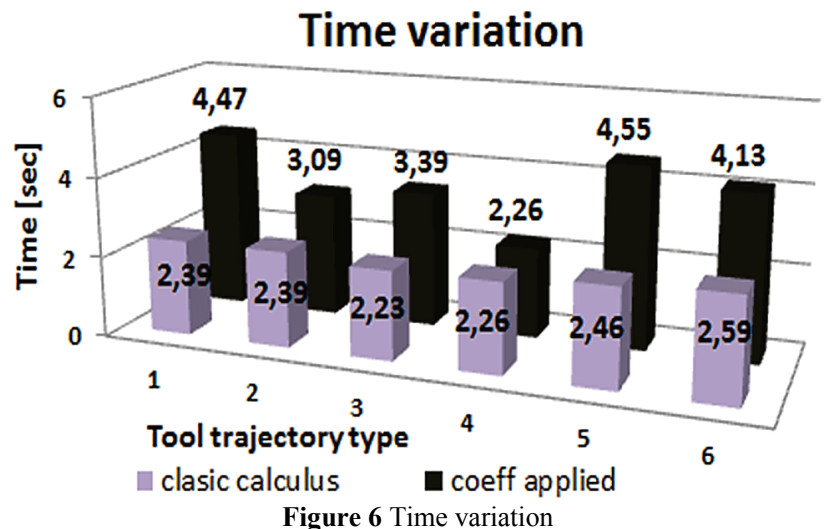

The values obtained for every tool trajectory after applying the correction coefficient are closer to the value of calculated cusp height. Also, we can observe that if the range of values is reduced and working with different tool path trajectories we can obtain similar surface quality.

Concerning the time variation due to reduction of radial step over, in the case of trajectory 2 , the increase of time is only $30 \%$ and the improvement of surface quality is $80 \%$.

\section{Conclusions}

Strategies chosen when machining free-form surfaces affect the resulting quality of the final product as well as cost per piece. Suitable combinations of strategies reduce total machining time, and will influence the surface quality of the free form surface.

From the simulations made we can see that after applying the correction coefficient on the step over, the values for the cusp height are reduced and the values calculated and simulated are closer. 
The forming of scallop height, when machining freeform parts, depends not only on geometry of the tool surface and the machined surface, the trajectory regarding the motion of the tool and a workpiece, but also on mechanical features of the material worked, dynamics of a machine tool, rigidity of a system and other factors. Taking this into consideration and in order to have good results and appropriate surface quality the simulation results and theoretical calculation must be validated by experimental results

The main goal of these tests was to establish some guidelines and calculus coefficient so that the CAM engineer is able to set up the best parameters according to tool trajectories type.

The aim of this research was to find the best surface quality so we used $c_{s d}^{\mathrm{t}}$ to decrease the radial step over. But by decreasing $a_{\mathrm{e}}$ the machining time will be longer. If the roughness requirements are not too high and the goal is to obtain short machining time the coefficient $c_{s d}^{\mathrm{t}}$ can be used to increase the radial step over.

\section{Acknowledgement}

The work has been funded by the Sectoral Operational Programme Human Resources Development 2007-2013 of the Ministry of European Funds through the Financial Agreement POSDRU/159/1.5/S/132395.

\section{References}

[1] Cao, Qingyuan; Zhao, Jun; Han, Shiguo; Chen, Xiaoxiao. Force coefficients identification considering inclination angle for ball-end finish milling. // Precision Engineering. 36(2012), pp. 252-260. DOI: 10.1016/j.precisioneng.2011.10.007

[2] de Souza, A. F.; Machado, A.; Fischer Beckert, S.; Diniz, A. E. Evaluating the roughness according to the tool path strategy when milling free form surfaces for mold application. // Procedia CIRP 14, (2014), pp. 188-193. DOI: 10.1016/j.procir.2014.03.089

[3] Souza, A. F.; Diniz, A. E.; Rodrigues, A. R.; Coelho, R. T. Investigating the cutting phenomena in free-form milling using a ball-end cutting tool for die and mold manufacturing. // Int. J. Adv. Manuf. Technol. (2013). DOI: 10.1007/s00170-013-5579-4

[4] Pena, A. E.; Anania, F. D.; Zapciu, M. Research regarding software developing for machining parameters optimization calculus. // Applied Mechanics and Materials. 656, (2014), pp. 192-199. DOI: 10.4028/www.scientific.net/AMM.656.192

[5] Ponomarev, B.; Paykin, D. Selecting Optimal Machining Strategy Parameters when Milling Complex Surfaces by Spherical Milling Cutters. // International Journal of Mechanical \& Mechatronics Engineering. 14, 1(2014)

[6] Cosma, M. Experimental studies on influence of tool path in 3-axes B.N.E.M. on inclined surfaces at 45 degrees. // Academic Journal of Manufacturing Engineering. 9, 4(2011).

[7] Soori, M.; Arezoo, B.; Habibi, M. Virtual machining considering dimensional, geometrical and tool deflection errors in three-axis CNC milling machines. // Journal of Manufacturing Systems. 33, 4(2014), pp. 498-507. DOI: 10.1016/j.jmsy.2014.04.007

[8] Wojciechowski, S.; Twardowski, P.; Wieczorowski, M. Surface texture analysis after ball end milling with various surface inclination of hardened steel. // Metrol. Meas. Syst. XXI, 1(2014), pp. 145-156. DOI: 10.2478/mms-2014-0014
[9] Mikó, B.; Beňo, J.; Maňková, I. Experimental Verification of Cusp Heights when 3D Milling Rounded Surfaces. // Acta Polytechnica Hungarica. 9, 6(2012), pp. 101-116.

[10] Stahovec, J.; Kandráč, L. Optimization of cutting conditions for the reduction cusp height in the milling process. // Transfer inovácií. 25, (2013), pp. 244-248.

[11] POKOLM - Technical Manual

[12] Pena, A. E.; Anania, F. D.; Zapciu, M. Research concerning optimum cutting parameters according with tool path strategy for finishing procedures. // ModTech, International Conference Modern Technologies in Industrial Engineering, 2015.

\section{Authors' addresses}

Andra Elena Pena, PhD. Eng. Lecturer

Faculty of Engineering and Management of Technological Systems University Politehnica of Bucharest

Spl. Independentei, nr. 313, Bucharest, Romania

E-mail: andra.pena@yahoo.com

Florea Dorel Anania, PhD. Eng. Lecturer Faculty of Engineering and Management of Technological Systems University Politehnica of Bucharest Spl. Independentei, nr. 313, Bucharest, Romania E-mail: dorel.anania@yahoo.com

Cristina Mohora, PhD. Eng, Professor

Faculty of Engineering and Management of Technological Systems University Politehnica of Bucharest

Spl. Independentei, nr. 313, Bucharest, Romania

E-mail: cristinamohora@yahoo.com 